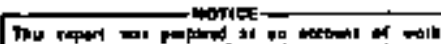

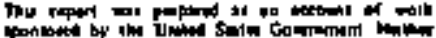

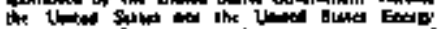

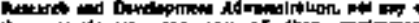

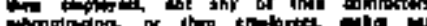

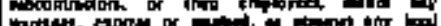

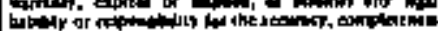

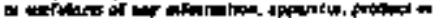

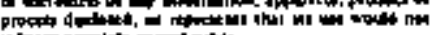

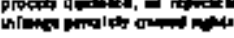

TECHNICAL PROGRESS REPORT

OF

BIOLOGICAL RESEARCH ON

THE VOLCANIC ISLAND SURTSEY AND ENVIRONMENT

FOR THE YEAR 1974

Submitted to

Division of Biomedical and Environmental Research

U.S. Energy Research and Development Administration

Washington $25, \mathrm{D} . \mathrm{C}$.

\title{
CONTRACT_NO: $E(11-1)-3531$
}

The study involves the terrestrial biological research on the volcanic island, Surtsey, off the coast of Iceland and the neighbouring islands and environs of the Westman Islands, which are situated on the MidAtlantic Ridge.

Principal Investigator: Dr. Sturla Fridriksson Reykjavik, Iceland. 


\section{DISCLAIMER}

This report was prepared as an account of work sponsored by an agency of the United States Government. Neither the United States Government nor any agency Thereot, nor any of their employees, makes any warranty, express or implied, or assumes any legal liability or responsibility for the accuracy, completeness, or usefulness of any information, apparatus, product, or process disclosed, or represents that its use would not infringe privately owned rights. Reference herein to any specific commercial product, process, or service by trade name, trademark, manufacturer, or otherwise does not necessarily constitute or imply its endorsement, recommendation, or favoring by the United States Government or any agency thereof. The views and opinions of authors expressed herein do not necessarlly state or reflect those of the United States Government or any agency thereof. 


\section{DISCLAIMER}

Portions of this document may be illegible in electronic image products. Images are produced from the best available original document. 
In 1974 research work was carried out on the islands of Surtsey and. Heimaey during the summermonths June through August. Two students stayed on the iblands and several soientific excursions were takẹn.

\section{TOPOGRAPHY}

Changes in the topography of Surtsey were quite noticeable. By comparing aerial photographs taken in 1974 with previous maps it is clear how the ișland is gradually being eroded on the south-western. side, and how the rim, of the Hestern-Bunki is being corroded down. (see frontispiece).

\section{MICRORIOLOGY}

During excursions in July Dr. G. H. Schwabe, MaxPlanck Institut für Limnologie, Plon, Germany, investigated the terrestrial algae.Lichen were studied by Hordur Kristinsson, Akureyri, Iceland. The lichens were noticed later than the moss but are now occupying higher levels of the lava. (Appendix I).

\section{MOSS}

The moss flora was investigated by Skúli Magnússon, who examined distribution and cover of the various species and measured the biomass in the fixed-quadrats. The microclimate in the moss habitats has also been studied by sogren as indicated in Appendix II. 


\section{VASCULAR PLANTS}

The number of higher plants found on surtsey in 1974 is shown in the accompanying table. Their location was mapped according to the same methods used in previous years (Appendix III).

The vascular flora on Heimaey was also investigated following the eruption that took place on the island in 1973 .

\section{ENTEMOLOGY}

Recording of insects was continued by the group of Swedish entemologists led by Dr. Högni Bddvarsson of Stockholm University.

\section{VERTEBRATES}

The ornithological studies were carried out by Erling olafsson. of major interest in 1974 was the addition of the black backed gull to the breeding birds on Surtsey.

SOIL

Investigation of further changes in the substrate soil were continued by Sveinn Jakobsson, who has studied palagonitzation of the tephra.

\section{OTHER ACTIVITIES}

A book on the terrestrial investigation has been written by the principal investigator Sturla Fridriksson and it is being published in 1975 by Butterworths, England.

The steering connittee is preparing the next volume of the Surtsey Research Progress Report, i.e., volume VII. This will contain papers published in the period 1971 onwards. 
On the accompanying list and chart of Surtsey are recorded vascular plant found on the island in 1974 . In 1973 approximately 1273 palnts were recorded and of these approx. 537 have overwintered. They are marked on pages 1-3 on the plant list with 169 number. When several plants of a species, which were offsprings of an old plant, were found growing together they were given the same number and marked with the same stake. In addition to the overwintering planst on the list are 90 plants that were staked out as new in 1974 . There were also 8 new Puccinellia maritima plants, offsprings of plant no. 72-90 in quadrat R-14. The mother plant of these eight seedlings disappeared during the sumner and had apparently been uprooted and eaten by a bird. Many new Honckenya peploides plants colonjzed Surtsey during 1974 in addition to those listed. These were mostly found on the eastern and central parts of the island as well as on the northern ness. Many are offsprings of earlier colonizers. In one instance, in quadrat $\mathrm{K}-17$, a Honckenva plant (No 68-56) had 50 offsprings, that formed a colony in the same quadrat and in the adjacent one, J-17.

The map shows locations of various vascular plants in 1974 as well as the number of individuals. 


\section{Overwintering plants in Surtsey 1974.}

Honckenya peploides

97

Elymus arenarius

Tripleurospermum

1

Festuca rubra

1

Mertensia maritima

1

Cystopteris fragilis

1

Cochlearia officinalis

Plants from 1972 and older living 1974:

Honckenya peploides

Cochlearia officinalis

Tripleurospermum maritimum

10

Cystopteris fragilis

Carex maritima

1

Puceinellia maritima

1

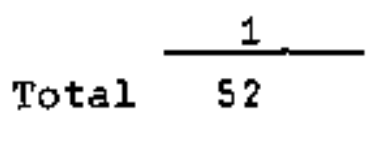

Total old Plants in 1974

New seedlings of Cochlearia officinalis 360

New seedings of Puccinellia maritina

8 


\section{List of MASCWLAR PLARTS}

- reoverad in surtsty 1974

\section{68-4-600 ONERWikTERAR ERON 1943}

No Species:

$68-2$ Honckencya peploides Honckenua peploidtes Horckenciga peploides

$67-3$

$68-22$

$68+23$

$68-24$

68.56

$68-63$

$68-64$

$68 \cdot 70$

$68 \cdot 83$

$68-87$

$69 \cdot 62$

$70-4$

$70-20$

$70 \cdot 25$

$70-31$

70.37

20.39

$70 \cdot 4 / 2$

$70-54$

$70-60$

70.64

70.72

.20.74

$3 i \cdot 35$

$71-43$

$71-16$

$71-47$

$7 f=54$

기-5?

$7 y-63$
$y-68$

$7 !-69$

$71-70$

$7-7 j$

ㄱ- 72

$71-75$
$72-30$

$72-34$

$72-37$

$72-40$

$72-41$

$72-42$

$72-56$

$72-53$
$-22-81$

$22-83$

$72-90$

mat
Honcke emma peloidso

Honckenciga profoides

Hondkenty a pepioideos

Honckenuna peptoideo

Honckeng pe pepoides

Honckenge peplendes

$$
\text { N }
$$

it

$\pi$

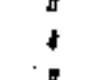

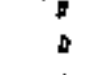

t

"

Corex maritima.

Cochlearia officinalis

Honckeniga peploidso

II

restod

Cochiearia Officinalis

Honckenya peploidas

Cochlearia officinalis

Cystopteris fraqilis

Cochlearia Afficinalis

Honckenty a peploidso

Cochtearia officinalis

4

Sipteurospermum mesitimum $5 \% / 4$

Cochlearia officinatis

Hanckenga peptoideo

Cochiearia' officinatis $5-4$

68-6 famost apters eftir
12-83 Honclemene puploides if 14 '

72-40 Pucciviellia sp. R $\mathrm{H}$

12.99 Horkakemeno peploides $E$ II

$72-108$

7) 109

$72-113$

$72-119$

F⿳一由八冂卄八

$73+4$

$73 \cdot 6$

$73-7$

$73-45$

$73-46$

$73 \cdot 48$

$73-50$

$73-51$

$73-53$

$75-55$

$73 \cdot 57$

$75-60$

$73-65$

$4-108$

$1+-1 / 2$

$|+/ 3|$

$N \cdot / 45$

$-165$

$-170$

.$/ 183$

$\cdot \cdot 255$

$1-245$

$\pi-272$

,-275

$-276$

$-208$

$m \cdot 282$

$-205$

a. -417

$\pi-289$

$n \cdot 305$

$n-3 / 7$

$+318$

- ito

3. 321

$n-312$

$n-324$

1. 344

is $\$ 77$

i1 348

- 344

1) 35 i

$\rightarrow 352$

1553

"

1355

1356

.357

1361

s

Costoplerio frogilis I 8

Hanckenca peploides I 4

. F i

Elumus arenertius I Is

Honckenys peplades $\frac{1}{1} / 8$

Elemans arenarius I/7

Honckener puploideo Gits

Clymas aremanivs .FB

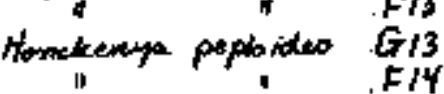

$F / 4$

C it

Kif

(x)

K.17

, 17

$4 / 7$

$2 / 7$

$L / T$

K/7

$k / 7$

$\mathrm{J} / \mathrm{T}$

$\mathrm{J} / 7$

$5 / 7$

J17

$.3 / 7$

. $/ 7$
N- 370

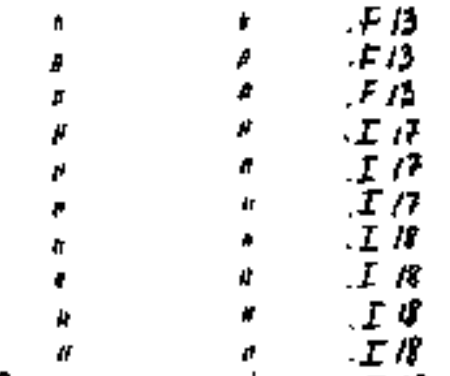

J/7

$x / 7$

K 17

, $k / 7$

$k / 7$

$k 17$

. 17

$k / 7$

. 17

$k \pi$

K H

$\boldsymbol{K} / 7$

14
73. $343^{\circ}$

$\pi \cdot 364$

$N+365$

$a+372$

Honckenya peptoideo "kit

"

Hanckersya peploides $L / l$

(1) 381

- $\$ 95$

358

+ 390

, 993

394

1395

iा 412

i 4197

1437

144

1. 44

- 448

1) $4 \%$

I 450

114 465

. 465

- 46

11 467

- 488

- 469

- 470

N 47

D 47

ก 47

\# 47

(1 475

I 477

. 478

- 47

त 480

त 484

. 502

- 503

is 504

a 507

1) 508

- 509

- 530

“ $53 \mathrm{~J}$

$\rightarrow 530$

i1 543

1) 545

- 567

- 580

त 586

, 587

11 588

" 343

i. 504

" 547

$\because 599$

1600

"

L/7

$K / 7$

KI

L. 17

$k / 7$

L/7

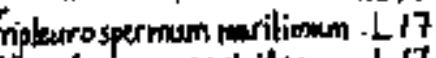

Honckenya peploides , L17

Clumeso aremarius . $1 \mathrm{Jb}$

Honckenga peptoiden $.4 / 6$

Edymuns aremartios .K. 17

Honckenga peptoides . t/7

Clumio aronatius .KI7

Henckenza peploriden .k18

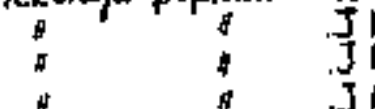

J 18

17

I 18

I 18

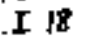

. 18

. 18

.118

.18

T 18

. I /

I

Elumeso aremarios IIt

Honckenya peploidso II

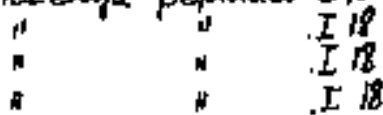

Elemous arenatius is Is

forckenya peplojdeo. I If

Elumus aremantius. If is

Honckeneya paphoides if If

Elymus antemamisos. I Is 


\section{New puaxts in}

\section{4}

\section{$7+5$}

74-1 ELymens aremanius. $I .18$ "I. -2 Hontkencya peproides $M / D$

H- 3

$n-4$

$n-5$

$6-6$

$A-7$

$y=8$

$n-9$

$p-10$

$n-M$

$n-12$

$n \cdot / 3$

". 14

$1 \cdot 15$

$n-16$

$n+17$

$n-18$

$A-19$

$n-20$

$m-21$

: -22

- -23

$a-24$

. - 25

, -26

N.27

a -28

- -29

N. 30

$-31$

- -32

- -33

$p=34$

$n-35$

$h-36$

A -37

$x-38$

$n \cdot 39$

40

41

$x+42$

$4-43$

a. 44

11 -45

1. 46

. .47

J. 10

$5-10$

$J=10$

$\mathrm{J} \cdot 10$

$\mathrm{J}-10$

$3-10$

$K-10$

$k-10$

$k-10$

J-a

* $\quad$ I $\quad \frac{I}{I}-10$

Cochiearia officinalis $0-7$

Honckenya peploides M-8

$M-7$

$M-8$

Merlensia maridima E-12

Elymus arenarius .E-12

Meriensia marikima, E-12

$$
\text { " }
$$

iI$$
\text { H }
$$

$D-12$

n

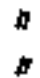

$. D-12$

$.0-12$

$"$ " $" D-12$

Elymus arenarias $\mathrm{C} / \mathrm{3}$

$A-13$

Mertenasia marilima. D. 14

Merdensia marilima. F-H.

$E-/ 2$

Elymus arenarius I- 18
74.48

$4-49$.

$74-50$

$11-51$

$"-52$

$4=53$

$a-54$

4.55

4i. 56

$4-57$

$4-58$

N. 59

i. 60

a. 61

$n-62$

$1 \cdot 63$

$a .64$
$i .65$

$n-66$

$n+67$

$x-68$

$4-69$

" -70

- - 71

$0-72$

1,73

$\cdots=74$

$\therefore 75$

$M-8$

Cakile edeniula $: D-12$

4.76

8.77

\%. 78

4.74

$-80$

$1-81$

$0-82$

s. 83

.84

$n-85$

4.86

$-87$

n. 88

$4 \cdot 89$

$-90$
Mertensia manitima $K-18$

Cochtearia officinalis. $J-18$.

Elymus aremarius

$k-18$

$k-18$

Merhensia maritiona $k 17$

" $" \quad k-18$

" $" k-17$

Elymuo aremarius $\quad k-17$

Mertensia marilima $\mathrm{J}-17$

$k-12$

Martensia mantilima

$K-/ 7$

Meriensia mantima $k-18$

Meriensia marituma $\quad K-16$

, $\quad \alpha-17$

" $\quad . \quad L-/ 7$

Mertensta marilima $L-17$

$\alpha-17$

$\angle-17$

$\alpha-17$

Oly $\quad L-17$

Alymens arenarius $k-17$

Mertensia maxitima $k-17$

u. Aidentified sp

$k-17$

Mertensia maridima $k-17$

Mertensia marilima $k-17$

Elymus arenarius : $K-17$

Medenesia martima $k-17$

Elymus arenarius $_{n}: K-/ 7$

Mertensia maritima $L \cdot L / 6$

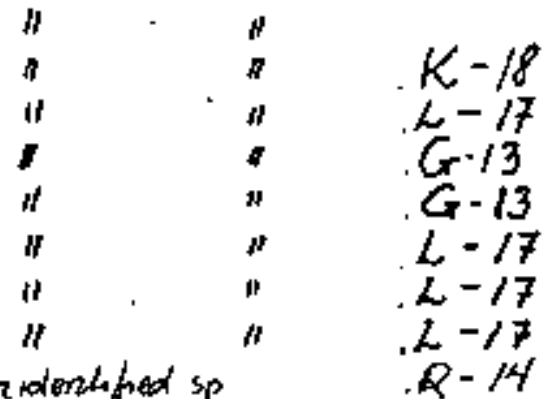

Elymess ar evarius

Puccinellia maritima $\mathrm{R}-14$ 
MOSS VEGETATION ON SURTSEY

Introduction. Moss was first found on Surtsey, in two locations, in the year 1967 (Jbhannsson, 1968). This situation prevailed during 1968 , and it was not until 1969 that moss was found to any significant degree. (Bjarnason and Frioriksson, 1972). The distribution chart for that year showed that moss had been found in 29 of the island's quadrats. In 1970 the distribution was even greater (Fridriksson et al., 1970 ), at which time it was thus clear that moss had finally colonized on the island. Until this year, observations had been somewhat random and directed solely at collecting samples of moss for analysis and keeping track of general distribution.

From 1969 to 1970 the number of moss species more than doubled, increasing from 5 to 16 . This fact, in addition to a great jump in distribution pointed to the need for more exact observation of the island's moss flora. It was therefore decided to organize a careful and systematic investigation of the island in 1971. A division of the island into quadrats (Frioriksson et al., 1968) formed the basis of this research, and each and every quadrate $(100 \times 100 \mathrm{ml}$ was investigated separately. This method produced a picture not only of general distribution but also of species count and the spread of each individual species.

In 1972 it was decided to carry out the same kind of investigation of distribution but to include observation of the habitat choice of a species and their coverage in these habitats, and thereby attempt to 
discover which species were found together in
communities and which species were typical for these
communities.

Research Prodedures.

1971: A careful search for mosses was made in all quadrats of the lava. It was deemed unnecessary to make such a careful search on that part of the island consisting of volcanic ash and sand, since moss does not appear to thrive in such environments.

An exception, however, was made in those quadrats containing fumaroles (such as $I-12$ and $H-13$ ). It was customary to confine the search for mosses to one quadrat at a time, and to cover this area thoroughly. The distribution of species identified on the spot was recorded on a chart, whereas samples of other species were taken for laboratory identification. A drawack of the sampling procedure was the way in which all samples from the same quadrat were collected in one box, which prevented a means of ascertaining a species' frequency of occurrence in a particular quadrat. The prodecure established earlier (Fridriksson et al.,1970) was used to determine general distribution. An aerial photograph, with the quadrat boundaries drawn in, and a compass were used in determining location within a quadrat. In making up the map showing general distribution for each species, a species was assigned to one of three groups according to its frequency of occurrence in that quadrat. (See Table I.)

1972: The area in question was combed in the same manner as in 1972. Collection procedures, however, were modified 
so that each sample was kept in a special container designated by a catalogue number and a quadrat number. Fon each species that was found in. a quadrat, the investigators noted the extent of coverage and the habitat at the first ten discovery sites in the quadrat. If the species was found in fewer than ten spots, then its coverage and habitat were noted at each location. Habitats were described as soon as they were observed, and were designated by a number that was used later for cataloguing purposes. The following categories were used:

1. Perpendicular lava cliffs in hollows and narrow crevices.

2. Moist sand. In caverns shaded by a lava formation, from which water drips onto the sand.

3. A thin layer of tephra on a lava surface; fully exposed and unaffected by fumaroles.

4. Same as Habitat 3, but affected by fumaroles.

5. Naked, exposed lava surface without" sand.

6. Hollows with sandy bottoms, moist and somewhat shaded.

7. Narrow cracks' in lava, filled with sand.

8. Sand, shaded moist, and warm from fumaroles.

9. Sand-covered lava, fully exposed.

10. Sand on a lava slope, partly shaded, and moister than in Habitat 9 .

11. Moist, naked, and shaded lava slopes.

12. Sand at the bottom of deep and narrow cracks in the lava; shaded. 
Coverage was estimated as the average cover of the species in its nabitat, which was determined with the use of a steel frane $(25 \times 25 \mathrm{~cm})$ that contained a wire mesh with equal squares Coverage was recorded in percentage, and the symbol + was used to designate coverage less than 1\%. In calculating the average cover for each species in the quadrats, t was counted as $0.2 \%$ coverage.

Information ahout a species' frequency of occurence in a quadrat was obtained later when the data was compiled. (Table I)

In addition to the above-mentioned details, investigators noted which species were found with capsules and gemma.

\section{Table I}

The following categories were used as criteria in determining the distribution symbols for each species in a quadrat:

\begin{tabular}{lll}
\hline Distribution Symbol & 1971 Categories & 1972 Categories \\
\hline & $\begin{array}{l}\text { Species found } \\
\text { often } \\
\text { Species found in Species found in } \\
\text { several locations } 2-9 \text { locations } \\
\text { Species found } \\
\text { once }\end{array}$ \\
\hline
\end{tabular}




\section{Conclusions}

General distribution: Between 1970 and 1971 the general distribution of mosses increased considerably on the island, but then decreased between 1971 and 1972. The clearest overview of these trends will be obtained by comparing the attached distribution maps with that from the year 1970 (Fridriksson et al.,1972).

The maps show that the main increase in the moss distribution occurred in the west, especially in 1971. Most of this area is on the southern slope of surtsey II, that is, in quadrats $\$-6$ and $J 8-9, K 5-10, L$ 6-9, and $M$ 6-9. In this area the lava is very rough, with 508 to 90 covered with volcanic ash (cf Fridriksson, Magnísson, and Sveinbjornsson, 1972, p.62). The area is very dry, with caverns and small overhangings that provide good conditions for moss vegetation. The species Racomitrium canescens grew in this newly colonized area in very small and widely-scattered patches, and was responsible for the increase in distribution between 1971 and 1972 in quadrats $J$ 5-6 and K 5-6. Mounds of volcanic ash limit the spread of moss to the north, since moss is not able to take hold there.

A minor concentration appears to have developed on the southeastern coast from 1971 to 1972 , and is probably the result of coastline erosion and, as a consequence, increased proximity to the sea.

Although the rate of change in the distribution boundaries was slower in 1972 than in the previous year, this does not mean that propagation in moss areas came to a halt, since the general coverage of moss steadily increases from year to year. 


\section{List of Species}

A great increase of species has occurred since 1970. In that year 16 species were known to exist on the island (cf Fridriksson et al., 1972). When samples from the summer of 1971 had been analyzed, the number of known species had risen to 37 , that is, an increase of 20 , or more than half the total number. All these new spocies were rare that year, except Bryum stenotrichum, which in all probability had arrived on the island earlier,but apecimens of which had not been identified as a distinct species as the fruiting bodies had not developed until 1971. All specimens had, up to this point, been recorded as Bryum spp.

It is significant that the first liverwort species to be detected on Surtsey, Marchantia polymorpha, was anong these new species. Two or three small individuale of this species were found on a rock in a moist hollow of a cavern in quadrat 0-17. After all the samples collected in the summer of 1972 had been classified, the number of species had risen to 72 , or twice the number noted in 1971. Like the new species identified in 1971, the new species in 1972 were all rare, found only in a few places.

Three new liverworts were added to the list of known species, but it did not prove possible to assign them to a species with any certainty. They are species of the genera Cephaloziella, Scapania, and Solenostoma, all of which belong to the Jungermanniales family. The Scapania species is a menber of either S. scandica or S. curta, whereas the solenostoma species belongs either to $\mathrm{S}$, atrovirens or S. pumilum. 
Each species is designated with a letter in the alphabet, according to its frequeney on the list, under the year column.

Reference to the accompanying list discloses that two species that were observed in 1970 and 1972 were not found in 1971. These are the specieg Aongstroemia Longipes and Brachythecium Salebrosum. Both were found in one place in 1970; in 1972 the former was found infwo quadrats, the latter in eight. This indicates that both species were present, but went undetected. This is particularly true of the latter species.

In 1972 three species on the 1971 list, Fissidens adianthoides, Dicranella schreberiana, and Pholia annotind were not rediscovered. There is reason to believe that $F$. adianthoides has died out on the island, in view of the fact that its precise location was known, that is, a small cave in L-12, where steam emission and optinum conditions were present. In 1972 the steam emission had ceased and a great deal of sand had blown in, so that the moss eventually dried up and perished for the most part.

The other two species are probably still subsisting, although there was no trace of them, but it is of course never possible, in terrain like that of Surtsey, to make a corroborative search. Thus, whatever rare species are found each year is largely a matter of coincidence. The species Bryum kingraeffii schimp., which was discovered in quadrat $\mathrm{H} 8$ in a tephra fumarole, had not previously been found in Iceland and is therefore new to the region. 
Species Distribution

The accompanying charts show the distribution of only the most common species, since there is not adequate space for a chart comprising all the species in a short anticle like this one. This omission is justifiable, since only the most common species have real ecological significance in the formation of soil and vegetation cover on the ibland. When reviewing the charts it should be remembered that they show only what the moss search revealed, and, as mentioned eariier, it was often coincidence that determined what species were found in a quadrat and the frequency with which they were observed. The frequency of species not shown on the map may be found in the distribution groups in the list of species.

Al1 the major species that were observed in 1971 spread greatly in 1972 , not a surprising fact in view of the rapid increase that was apparent from 1969 to 1971. Unexpected, however, was the spread of the species Grimgia stricta and_G. apocarpa in 1972 , both which were found in 1971 in only two quadrats. By 1972 they had become common species and were often found with capsules.

Difficulties in classifying Bryum spp. made it necessary to represent their distribution combined on one chart. The Bryum species are among the island's most common, but it is not yet possible to state with any precision the role of each species in the general distribution. (Exceptions are B. argenteum and B. calophylium.) It was possible to map the distribution of particular Brym species as some specimens bore capsules and could be classified with certainty. 
There is no doubt, however, that Bryum stenotrichum is the most comnon Bryum species on Surtsey, since by far the greatest number of capsulated specimens that have been found are of this species.

The Philonatis spp. chart shows the general distribution of all philonotis species on the island, that is to say, if there are any other species than P. fontana. It has been possible to assign only a few specimens to a species, and they are all of $\underline{P}$. fontana, so it is likely that nost of the Philonotis samples belong to this species. These classification difficulties stem from the immaturity of the specimens.

\section{Sporing}

The following table shows which species were found with spores in 1971 and 1972 their location: 
When a species reaches the stage of forming spores and capsules, its chances for spreading on the island are no doubt increased all the more. But in general it is not known exactly to what extent propagation by spore contributes to the increase of each distinct species. In addition to sexual reproduction, asexual reproduction by means of gemma and other plant parts is very common.

Gemma (asexual reproduction) have been found on the following species:

Marchantia pol ymorpha

Bryum Klimgraeffii

Bryum palleng

Pohitia proligere

Pohlja annotina var, decipiens

Pohlia_schweicheri

Although asexual reproductive organs have been found only on those species mentioned above, it is certain that other species have propagated asexually on the island, that is, with plant bodies, such as leaves and stalks, which break off the parent plant and are carried to a new location where they form new colonies.

\section{Fabitats}

As indicated earlier, investigators recorded the various habitats for each species observed in the different quadrats on surtsey.

The following table represents the conclusion of these observations for 23 af the most common species. on the island. They are arranged according to distribution, with the most common listed first, and so forth. 
This arrangement, however, does not apply to the Bryum species, except B. argenteum, which is easily identifiable with the naked eye. The others were recorded as Bryum spp.

The frequency figures indicate how often species were recorded in the various habitat categories. Thus, for example, the species R.canescens was recorded at a total of 966 locations, being in the habitat category No. 5 in 954 instances. The highest frequency figures for each species are underlined in the table, thus showing the most common habitats of the species.

According to the number of samples, category No. 5 is the most common habitat on the island. It is favored by various species, such as Racomitrium canescens and R. Ianucinosum, Grimmia stricta and G. apocarpa, all of which can be said to be characteristic for this habitat.

These four species seem to thrive well on the island but have not yet undergone the competition that will show which one will eventually dominate this community in the future. Several other species were found growing in this habitat, but they are so far only associate species in this primary succession. An example of these is Bratramia ithyphyllag, a species which also grows under various other conditions.

An other common habitat on Surtsey in the category No. 6. It is favored by many species, such as various Bryum species like B. stenotrichum, as well as Funaria hygrometrica, which are still the most dominant species. Associate species are 
Pohila sruda, Philonotis sp., Ceratodon purpureus, Bartramia ithyphylia, and others.

The other habitats can be examined in the same way as these two.

This classification is based on 4.593 observations. Claspical sociological measurements could not be applied because the moss colonies are still rather scattered.

\section{Cover}

The total cover of mosses on Surtsey is still rather small, and exact measurements of their coverage are therefore very difficult to obtain. The roughness of the lava surface also adds to these diffioulties.

As mentioned above, the cover of each species in its habitats was recorded in each quadrat. The accompanying cover maps show the mean cover value in each quadrat for the six most common species.

The maps reveal that although Racomitirum canesciens is the most common species on the island, it ranks only third in coverage, the patches being usually much smaller than those of Bryum spp. (mostly stenotrichum) and Funaria hygrometrica, which show the highest cover valies. Other species have much less average cover per quadrat.

\section{Acknowledgements}

Bergbón Johannsson of the Museum of Natural History, Reykjavfk, has checked all of the classifications on which this paper is based, in addition to classifying all dubious specimens. The writer extends his deepest thanks for this invaluable assistance.

The work on which this paper is based was sponsored by the Surtsey Research committee, with a grant from the U.S. Atomic Energy Commission Div. of Biology and Medicine, under contract No. AT(11-1)-3531. 


\section{REFERENCES}

Einarsson, E. 1968 :

Comparative Ecology of Colonizing Species of Vascular plants.

Surtsey Res.Progr.Rep. IV. p.9-22

Fridriksson, S.and Johnsen, B.1968

The Colonization of Vascular Plants on Surtsey in 1967.

Surtsey Res. Progr. Rep IV. p.31-38

Johannsson, B. 1968:

Bryological observations on Surtsey

Surtsey Res. Progr. Rep. IV p. 61

Fridriksson, \$. 1970:

The Colonization of Vascular Plants on

Surtsey in 1968 .

Surtsey Res. Progr. Rep. V. p. $10-14$.

Fridriksson, S., Bjarnason, A.H., and Sveinbjönsson, B. 1972:

Vascular Plants in Surtsey 1969

Surtsey Res. Progr. Rep. VI pp. 30-33.

Bjarnason, A.H. and Fridriksson, S. 1972:

Moss on Surtsey, Summer 1969

Surtsey Res. Progr. Rep. VI, pp + 9-10

Fridriksson, S., Sveinbjothsson, B., and Magnússon, S. 1972:

Vegetation on Surtsey Summer 1970

Surtsey Res. Progr. Rep. VI. pp. 54-59

Johannsson, B. 1971 :

Islenzkar mosategundir. Skrá. 
Nyholm, E. 1954-69:

Illustrated Moss Flora of Fennoscandia. Musci.Fasc. 1-6 Malmo and Lund, Sweden.

Watson, E.V. 1968 :

Eritish Mosses and Liverworts

Canbridge, England

Hesselbo, A. 1918 :

The Bryophyta of Iceland

Bot. of Iceland. 1:395 677 


\section{Lichen Colonization in Surtsey 1971-1973.}

Skýrsla til surtseyjarfêlagsins 1 Jankar 1974. (ekki atlas bbreytt til prentunar)

Lichens vere first detected on surtsey in the summer of 1970, when three species vere found on the island, Trapelia coarctata, Placopsis gelida, and stereocaulon vesuvianum ( $\mathrm{H}$. Kristinsson 1972). The present article deals with the results of three visits to surtsey, in June 1971, July 1972 and in August 1973 , when $2-3$ days were spent there each year.

METHUDS.

Different habitats were searched for inital stages of lichens throughout the island by the aid of hand lens. Samples were collected of all species detected in the fieid. Final identification was carried out in the laboratory by microscopical vork and comparison vith knorn samples fron the mainland of Iceland, whenever such vere availabie. In certain cases chemical analysis by thin layer chromatography was used to verify the identification. These methods have been described in deteil by C.F. Culberson \& H. rristinsson (1970). All species found in sartsey were numbered for convenience, so that even unidentified species could be referred to in this and eventully in subsequent papers.

The distribution of 1 ichens in surtsey was recorded by the aid of the local grid system of $100 \times 100$ squares, already used for the distribution of vascular plants and mosses (s. Friflksson et al. 1972). All squares vere visited at least once, and the more comon lichens were noted in the field, but all others collected for later identification.

\section{LIST OF SPECIES.}

1. Trapelia coarctata (Sm. \& Sow.) Choisy. First found in surtsey 1970 on the north facing rocky slope on the outside of the crater surtur II. It is widely distributed around the craters surtur II and surtur I, and also found in the lava 
field south of surtur II, where stean emission is still efficient, but nowhere else. Under such conditions its grouth rate is very rapid.

rrapelia coarctata forms in surtsey light brown to whitish thallus of several cn dianeter. Apothecia are always present in great number, formed below the thallus surface, and brake through the cortex as they get mature. The apothecia are dark brown, $0.30 .5 \mathrm{~mm}$ across, vithout exciple, but bordered by the ruptured cortex, until they get old. Epithecium and hypothecium brown, the hymenium 120-150m, the ascospores 12-20 $\mathrm{x}$ 7-11 $\mu$. colorless, subgrobose to ellipsotd.

2. Placopgis gelida (L.) Linds, was first seen 1970 in the same locality and habitat as Trapelia coarctata. Next year it was found in several localities in the most recent lava field which came up 1967. In contrast to Trapelia coarctata this species is nov distributed throughout rost of the lava fields independent of the stean emissions.

In the first stages of this lichen, scattered, white thalli are found distributed like dots through a patch of 2-10 $\mathrm{cm}^{2}$ diameter. Their grovth advances relatively fast, and soon small cephalodia are seen at the margin of many of the thallus dots. Through subgequent growth the thallus pieces finally coalesce and cover the roak surface to form a coherent thallus of the same diameter as the original patch. In that stage the thallus has lobed margin and is dotted with many brom cephalodia. The largest thallus measured had a diameter of $6 \mathrm{~cm}$. Soredia are soon formed in round soralia on the thallus surface, but no apothecia have been seen in surtsey. and they are not frequent in Iceland el ther.

3. Stereocaulon vesuvianum Pers. appeartefirst on the lava fields north and northeast of surtur II and in the northern outside slope of the same crater in 1970 , Doth habitats ingluenced by varm steam. In the next year (1971) it vas seen at several localities in the lava fields fron 1967. where $i t$ now has a wide distribution independent of the steam holes. Itg distribution extends al so to the lava of 1965. but it is still lacking in some parts of $i t$.

stereocaulon vesurianum appears first as small, rounded 
warts (phyllocladia) scattered throughout the surface of the lava, either groving single out of small arr bubbles, or frequentiy concentrated along delicate surface cracks of the rock. For that reason it grows frequently in long and narrov lines. The phyllocladia are not grouped into round plots, like Placopsis gelida and stereocaulon capitellatum. As the growth advances, a dark, depressed spot appears in the center of the phyllocladia, a characteristic feature of the phyllocladia of $\underline{s}$. vesurianum. In general the developwent of this species is in Surtsey still at the stage of single phyllocladia. The growth is very slow, only at a fer favorable sites had it in 1973 already formed about 4 ml long, erect pseodopodetia vith many phyllocladia. Neither soredia nor apothecia vere seen. Even cephalodia have not been noticed in the surtsey specimens, but in Iceland the species generally bears cephalodia vith ei ther lostoc or stigonema as parasymbiont, occasionally both occurring on the game plant.

4. Stereocaulon capitellatul Magn. In 1971 small, more or lesg erect, light grey lichen lobes vere found in different places of the lava field of 1967 . The single lobes vere $1-2$ min in diameter. but growing scattered in patches of $1-3 \mathrm{~cm}$ diameter. The lobes vere partly with recurved margins, on which the underside or the margin broke up to forn soredra. Thin layer chrowatograpby of such lobes showed that they produced the same combination of compounds as found in stereocaulon capitellatum and s. farinaceum (lobaric acid, anziaic acid, and perlatolic acid). In 1972 and 1973 the recurved lobes 3 tarted erect growth at favourable sites, to fors pseudopodetia vith spherical soredial heads, typlcal norphological feature of these same species. At the sane tame cephalodia vith Nostoc vere found interspersed between the pseudopodetia of vell developed specimens. At present this species has almost as vide distribution in the lava fields as s. vesurianum and placopsis gelida. It is not obvious to which of the tro species these young plants belong, but the substrate vould rather indicate s. capitellatum, since s. farinaceup generally grows on soil.

5. Leprarid incana (L.) Ach. In the suminer of 1971 attention was paid to light green patches interspersed vith dark green algal coats on overhanging rocks and cave mouths throughout the lava fields. The light green thallus consists 
of one-celled green alga of Trebouxle type, enveloped by fungal byphae. The surface of the thallus is at first crustose. granulose-verruculose, but soon the total surface breaks out into soredia. Apothecia are never produced on this thallus, vhich is classified to the genus hepraria.

The species found in surtsey is very comnon in Iceland on overhanging rocks and in cave mouths, and was by earlier authors called Lepraria latebrarum. I have seen specimens of this same lichen collected by Lyage and identified as L. aeruginosa. According to P.W. James (1970) the correct name for. L. aepruginosa is H. incana (L.) Ach. But othervise the identity of this species must be considered uncertain. The taxonomy of this genus is rather inconplete because of lack of good morphological criteria.

6. Acarospora. In one sample collected on the north slope of sprtur II in 1971 there were some sterile thallus lobes, which on better samples from 1972 could be identified as Acarospora. In 1973 this same species vas found in several other localities. It is fairly frequent on the margin top of surtur I and in the slope below the top, and it also occurs on bird-manured lava outcrops.

The thallus consists of small squamules, about 1 or maximal 2 across, pale grey-brovn to straw-colored, single or more of ten crouded together, each $w i$ th the lobe margin recurved. On older squamules there are one to several brow, immersed apothecia. In section the hymenium measures $120-150 \mu$, the ascospores are many hunderds per aseus, 2.5-3 $21.2 \mu$. This species has not been identified yet.

7. Eacidia. One species of Bacldia vas found 1972 in the restern outside margin of Surtur II, groving anong Trapelia coarctata and Acarospora 6. Only small sample was available of this species, and it has not been finally identifleo.

The thallus is axeolate-verrucose, lightcolored, pycnidia abundant, apothecia dark brown to blackish, short stalked.

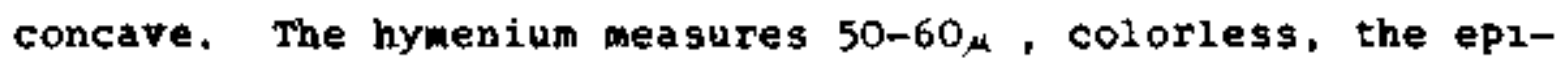
thecium brow, the hypothecium colorless, paraphysae sinple. vith brom head at top, the spores hyaline, 4-celled, 20-30, 1 ong. 
8. Lecidea. At the same locality as Bacidia 7 , a species of tecidea vas also collected in 2972. The thallus is thin, light colored, slightly areolate, the apothecia sessile, black, first concave, then plane, vith elevated margin. The hymenion measures $100-120 \mu$, colorless, the epitheciun is dark brown to black, the hypotbecilam aark brown, the excipulun blackish near the outside, the ascospores colorless, one celled, 22-15 $\times 7-9 \mu$.

\section{Lecided. Another species of Lecidea was detected} in a sample from the vestern spe of surtur II collected in 1972. The thallus is sorediate, ochraceous, the soralia are erumpent, blue-grey, round and clearly delimited, about 0.10.3 m across. No apothecis vere present. An identification must arait for better samples, and better knovledge of the Icelandic species of the genus Lecidea, than ve have nov.

10. Xanthoria candelaria (L.) Th,Fr. This species vas seen in one locality both 1972 and 1973. Several plants vere found in an area of $1-2 \mathrm{~m}^{2}$ around a spot where an artificial plastic pool had been set up as a trap for fresh vater organisms (Maguire 1968). This species is foliose, but the thallus lobes are narrow and more or less erect, of bright orange-yellow color. It is very comion throughout Iceland on places where birds rest, on top of boulders, rock outcrops and fence posts.

\section{Arthonia. A specimen provisionally referred to the} genus Arthoniz vas colveted 1973 on exposed rock around a lava peak in the lava field from 1967. Acarospora was found on the $\checkmark$ top of this sane outcrop, but the rock belov the top vas overFrown with Arthonja. Besides groving drectly on rock, its thallus al go extends over hardened accumulations of volcanic ash in the atr bubbles on the rock surface. The thallus is very thin, hardly visible, the apothecia are black, tiny, $0.05-0.2$ ma in diameter. plane to slightly convex. The hymenium is 40-50, high, the epithecium greenish black, the hypotheciun colorless, the exciple darkened. The ascospores are colorless, $8-21 \times 4 \mu$. inequal tro-celled. 


\section{HABI TATS}

The lichens presently known fron Surtsey grow in four different habitats:

1. Rocks influenced by yarm steam. This habitat is found all around the craters surtur $I$ and II. The steam comes owt of small holes which open out through the elevated crater margin or in the surrounding lava field. The condensation water from the steam keeps the surrounding lava surface vet. The steam is blown by the wind, so that some areas are only

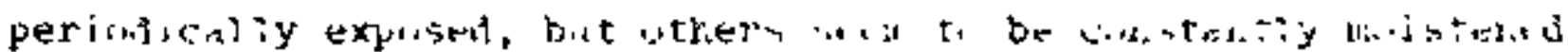

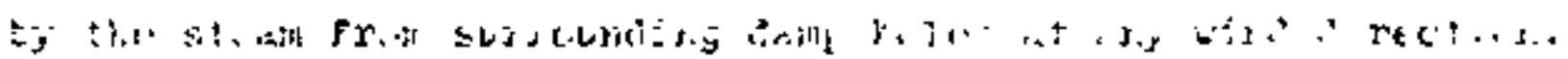

The steady supply of vater provided by the stean is of primary significance to the lichen grovth in this babltat. Even though olichens in general can survive Iong periods without vater, they stop growth as scon as they get dry, because they have no vay to maintain water in the thallus by dry air condituons. The speed of growth is therefore directly related to the length of time they are kept moist.

The raised temperature caused by the steam is probably only of secondary importance. At a certain distance from the hole lichen growth may be promoted by the ralsed temperature, but around the opening their development is prevented by the heat.

The most successful colonizer of these stean habitats is Trapelia coarctata, which apparentiy grows and distributes very rapidly under these conditions. It has not been found in any other habitats in surtsey. When originally found in 1970, it had already thousands of mature apothecia, so that local dissenination probably had taken place for some time in surtsey. sone indications vere seen for distribution by rain vater ronning down the slope.

Another nember of this community is elacopsis gelioa, vhich develops well under these conditions, but is not oependent on the stear water.

Bacidia 7, Leçidea 6 and tecidea 9 , all only found in one sample, vere collected in this same babitat. Otber lichens, like Stereocaulon vesuvianum and Acarospora, which actually belong to other babitats, as will be pointed out later, vere also first found at the crater margin, simply because their grovth was faster here than el sewhere. 
2. Bird manured rocks. There are plenty of 2 ava outcrops in Surtsey, which are characterized by frequent visits of birds, which both can act as dispersal agents and also as providers of nitrogen. Most of these outcrops, however, are still devoid of vegetation, prinarily because vater is too scarce. The first colonizer of these habitats in surtsey is Acarospora 6 . It is found at several localities on lava peaks and on the margin tops of surtur $I$ and Surtur II. It developes faster where it enjoys the noisture of a varm steam. It is presumed, that the extreme dryness of most exposed lava peaks is probably the reason why the development of this community advances slovly and onlynin relatively fev places.

other colonizer of a similar babitat is Xanthoria candelaria, which only occurred in one localjty, around a plastic Fresh vater basin, set up 1967 and later removed again. This is a species, wich generally grovs on bird manured outcrops like the Acarospora. In surtsey, hovever, it either did not happen to be carried to such places, or they are too dry for it. The fresh water basin acted as an attraction for seabirds, and this vas stationed on a less exposed spot than most of the bird manured lava peaks, and therefore offering better vater conditions. The propagules of Xanthoria candelaria were probably brought in by bjrds, which washed them off in the vater, and then splashed them afound. This idea is supported by the single occurrence at tinis one locality, and by its frequency vithin the splashing distance from the vater basin.

3. Qverhanging rock valls and caves. Only one lichen species Lepraria incana, is found ir this habitat, which is charachterized by its shade, and moist, stagnant air. Besides the lichen, a species of a green alga of chlorococcus type is also videly distributed in this sane habitat.

4. The lava fields. The dry rock surface of the lavalields represents the most videly distributed babitat of all, but it raises higher denands to the vater deficiency tolerance of its inhabitants, than habitat 1 and 3 . Consequently is the growth in this habitat generally slov, and there is a marked difference between the exposed lava peaks, which quickly dry out, and the deeper depressions and hollovs, where the moisture is longer preserved. The vater supply is evidently the factor. that limites the speed of growth here. The initial development of this vegetation starts in small air bubbles on the rock surface, these serve to accumulate diaspores and dust brought by 
the wind, as fif 1 as to keep the drying effects of the vind away and preserve the moisture longer than is possibie on the smooth rock surface. Small cracks or fissures on the rock surface al so serve sinilar pospose.

These dry lava fields are colonized chiefly by. three species of lichens: Stereocaulon vesuvianum. S. çapitellatum and Placopsis gelida. Several mosses belong to the same consunity. mainiy placonitriun Ianuginosum and R. canescens. Especially placopsis gelida grows much more rapodly in the depressions, and the same applies to phaconitrium. Stereocaulon vesurianum seems to have the highest tolerance for vater deficiency, it is a siov gforing species, and relatively indifferent to the position of. its habitat.

\section{DISTRIBUTION}

During my first search for lichens in the lava filds of Surtsey (1968, 1970), primary attention vas paid to the oldest lava from 2965, gince vegetation development vas expected to start there. Nevertheless, the colonization of lichens and mosses started in the new lava flov from the last effusive phase of the eruption in 1967. In 1971 both the stereocaplon, placopsis and Rhacomitriug vere videly distributed there. but could hardly anywere be encountered in the lava from 1965. still in 1973 the vegetation of this lava was extremely scarce, and large areas of it vere completely devoid of vegetation.

In an effort to find the explanation of this difference, it was noticed, that the surface structure in certain parts of the new lava (the Aa lava) is more porous than the old lava, vich probably means improved water retaloing capacity. . The colonization has been more successful in this part of the nev lava, than el sewhere in the lava fields. But even in those parts of the nev lava, vhich have a very hard, glassy surface. colonization is much further advanced than in the older lava of 1965. Consequently the surface structure can not explain the more advanced colonization there.

The presence of a trace of some toxic substances has al so been suggested as possible reason, but no support for that hypothesis has been obtained from cbemical analysis made by the geologists.

Another and a more satisfying explanation of the different success in colonization of the old and the nev lava suggests that the retarded grovth in the old lava is due to lack of vater, causec 
by heat emission, which ories out the rock surface more quichly than in the new lava, where apparently no heat emassion occurs. Although not perceptible in the field during summer, this heat enisgion has been demonstrated by air photos taken in the vinter. Vhile thin snov layer covered the lava from 1967, large parts of the old lava remained free of snow.

Ho $l i c h e n s$ at all have been found anywere in the northern part of the island, nej ther along the shore nor in the palagoni te area.

CONCLUSTONS ABOUT LICHEN TRANSPORT TO SURTSEY.

There are no direct observations avaliable on how the 11 ijchen species vere brought to surtsey. No success vas made by searching for lichen propagules on the feet and plumage of birds caught in surtsey and made available through Dr. sturla Fridriksson 1969 and 1970 , al though some other plant material was found, like green and bluegreen algae, moss parts, fern sporangia, and tissue fragments of vascular plants. It vould have been of interest to have samples taken of the air plankton around surtsey, to investigate $i$ ts content of lichen and inoss diaspores, but no attempts have been made in that direction.

Through indirect observations it seens reasonable to conclude, that at least 4 species (stereocaulon vesuvianum. S. capitellatun, Placopsis gelida and Lepraria) arrived by air to surtsey, and that one species (Xanthoria candelaria) was born there by bircs. For the 6 species left, no conclusion has been made.

The foux species supposed to come by air, vere all evenly distributed throughout the island, wherever the appropriate conditions for their growth were present, before any local dissemination could be accomplished. No dispersal agents other than the vind could possibly ensure for such an even distribution into every small corner in the lava fields in these fev years. All of these four species do form soredia whicn can be air born, and simultaneously carry the green algal land the fungus. Three of the species have cephalodia vith blue green algae (Nostoc) and these appear later than the mycobiont and the green algal symbiont. I presume, that they distribute separately by air and are captured by the fungus. Free Nostoc colonies have been

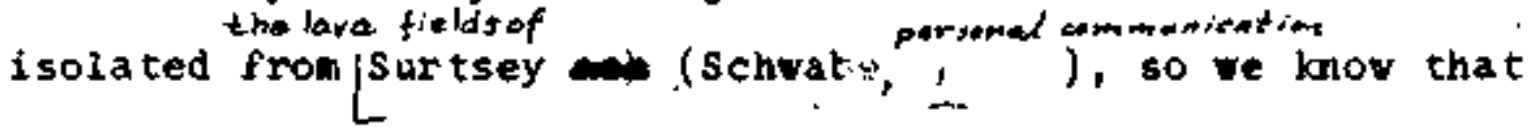


they get there. We do however not know for sure, whether free living Nostoc cells can be captured by the fungus to form cephalodia in stereocaulon or placopsis, even though this has been suggested for peltigera aphthosa (Hale 1967), or whether some special physiological adaptation is needed for the lifein the cephalodia.

Three of the four species do form ascospores in Iceland, but sparcely compared to the soredia.

xanthoria candelaria, which is apposed to have arrived by birds, vas until 1973 only found at one locality, but many plants vere vithin 1,5 meter distance from the spot, where one of the fresh water basins was stationed fev years before. It probably vas born by birds inte the basin, then washed off in the water, and splashed arourd.

This species does sometimes form ascospores in Iceland, but distribution by air born ascospores to surtsey vould hardly result in several plants in a plot of ca $2 \mathrm{~m}^{2}$ size, vith all other parts of the island uncolonized. Soredia are not formed by $x$. candelaria, but the finely branched, erect lobes do very easily fragment, and have a guitable shape to get attached to birds. The probability of being carried by birds increases through its habitat, since it is coprophil and specializes in the resting places of birds.

of the six species about which no conclusion vas made concerning their transport to surtsey, five appear to reproduce by ascospores, and one, lecidea 9, by soredia. Most of them were first found on the elevated crater margin of surtur II. They could easily be air born, and the reason that they first appear at this locality may be simply because the enditions for their grovth are best there, due to the condensation vater from the steam emissions. If that is the case, they vould be expented to turn up in other places later. Consequently we do not need birds to explain their presence there. Because of the tremendous tranpport and dispersal capacity of the vind, the role. of birds is in ay opinion negligible for species with effective vind distribution. Only in cases, where vind distribution fills for some reason, occasional bird trapsport becones important. on the other hand, the crater margin of Surtur II projects several meters above its surrounding and is frequently visited by birds. 


\section{REFERENCES}

Culberson, Chicita F. Horour Kristinsson. 1970. A standardized Method for the Identification of Lichen Products. Jour, Chronatog. $46: 85-93$.

Fridriksson, Sturla, Agóst H. Bjarnason and Bjartmar Sveinbjornsson. 1972. Vascular Plants in suresey 1969. Surtsey Research Progress' Report 6: 30-33. Hale, K.E. The Blology of LAchens. London 1967. Kristinsson, Horour. 1972, Studies on Lichen Colonization in

surtsey 1970. Surtsey Research Progress Report 6: 77 . Maguire, Bassett. 1968. The Early Development of Freshvater Biota on Surtsey. Surtsey Research Progress Report 4: 83-88. 
Temperautres, steam cmission and moss cover in the Unertual areus of the island of Surleav, Iceland

By

ERJK A. SJÖCREN

Instilute of Ecological Bolany, LTpgsala Universiti. Swetler

\section{INTRODUCTION}

In August 1972, four days were spent on Surtsey, 12-15/8. In the ycars after. 1968. colonization by mosses, on the island bus been followind in delail (ril. Biarnason - Fridriksson, 1972! Fridriksson - Bjarnason - sreibljijinsson, 19:2: l'tidriksson- Svcinbjörnsson - Magnusson, 1972\}. The largest patches of de:se moss cover are found in the thermal area of the island (cf. Mapnusson- Svenul.jörusson Fridriksson, 1972). This does nol mean, hovever, lhat the ta rogest number of recorded localities with primarv colonization lw bryophyles are to he loutul wilhin the thermal area.

At he beyinning of $\mathbf{1 9 7 2}$, I received the generous imviation of the Striser Research Societv to come to Surtsey. Mv intention put forward al that time was to study microclimatic conditions in the thermal aren in plices where moss cover was present. Tha main questions to be studied were the inlluthce ol lient, sleim and windiransported malerial (accumulation and crosion) on colonization in: inosses.

A "Grail multipoint temperature recorder, model D, was used for the temperature recordings. Wt th this inslrument, it is possible to sccord cemperitures rrom 28 diermistor prolses within 3 minutes, i.e. almost simultanousli. The recordings are made automatically at intervals of one hour. Reading the recorded values, and calibration of the instrument, including the necessary use of a consersion chart, allows the measurement of temperaiures to $\pm 0,2^{\circ}$. 
The prolyes used during the measuring serie's were equipred will baldiation sholiers of aluminium feil. The full capacity of the instrumem could not be used, as there wore difficull problems with short circuit because of the permanent steam in the measuring aroas.

Meleorologica) measurements in August on Surtsey (cf, Sigiruggsson, 1970 p. 119) indicate a mean temperature of $10.7^{\circ}$, wilud velocitv at $2 \mathrm{~m}$ aboie giround level of $3,9 \mathrm{~m} / \mathrm{sec}$. (13 dnys) and precipilation of $25,4 \mathrm{~mm}$ (13 days).

\section{MEASURING AREAS}

A. A tatal of $\mathbf{1 3}$ probes were seattered withis and in the viritith of the so-coniled tephre and "Bell". which is a cave jormed by accunitaled sind. It has a W-facing entrance and a hole in the roof. The "Bell" is situated in the scction $\mathrm{J} 13$ (110 $\mathrm{m}$ alsove mean Bea levely to the NE of the somallod Surtur I erater (ch. belowil. It is situated on a S-facing slope with an inclination of aboul $30 \%$. Th the area are numerous stowm-emilting holes. Stean comes out continuously from places in and close to the care. Moss cover is concentrated in the vicinty of the sten holes. in the iulerior of the crve and at the top of the cave where the sand is pormathenly moist, in this locali-

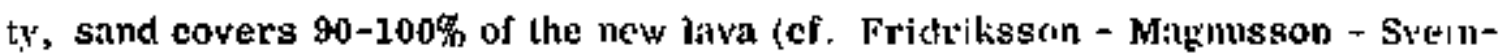
björnssom, 1972).

B. A total of 21 probes were plnced in the northern part of the crater "surtur 1 " (local names of. Thórarinsson, 1968 p. 143-14s) in the section L 12. "his part of the crater has very many steam lissires and holes. There is continuous condensiLion of water in the area, and the accomulation of sand is considerable 17 probes were placed within the crater; 2 prohes on the northert rim; and 2 in a place will. no stean emission. E of the rim. Moss cover is frequentiy present close to places of steam emission. The degree of cover within sample plols of the size $1 / 4 \mathrm{~m}^{2} \mathrm{cx}-$ ceds $50^{\circ}$ in several places. 


\section{RECORDINCS}

A. Ioctalin: "True Brill".

Tine period: $12 / 814.00-14 ! \$, 13.00(1972)$.

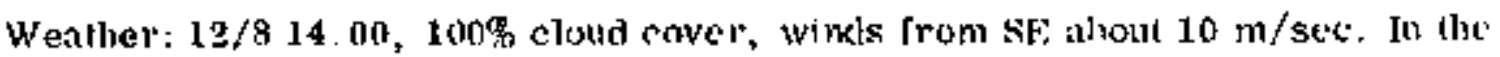
night 12-13/R, strong winels and seallered rain showers. 13/4 12,00. Henerallt 1006 choud cover, winds from W-SW. alhout $15 \mathrm{in} / \mathrm{sec}$, scallared ritin showers.

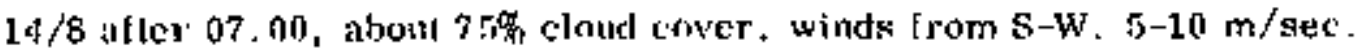

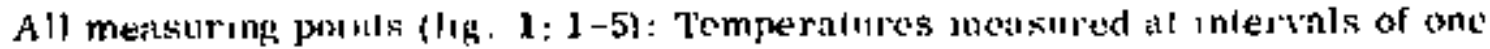

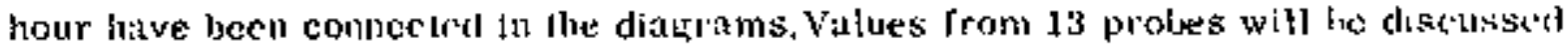

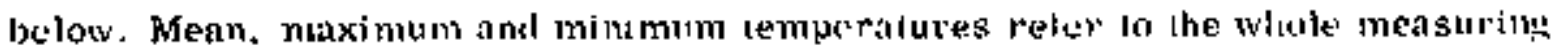

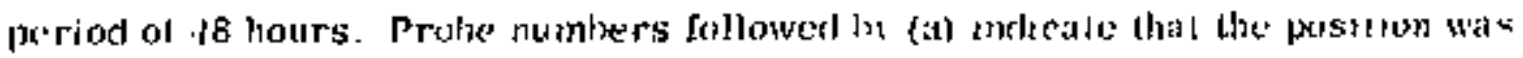
belisw the soll surtare. If followed ly (h) the frosulion was al the soll surtace.

Pooleses 10 and 2 's (fig. 1 . h).

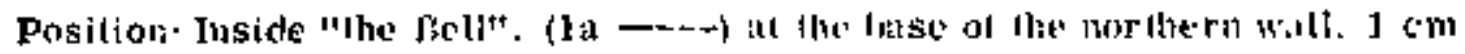

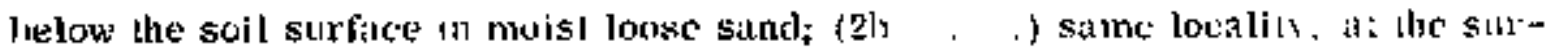
filce.

1:1. max. $19.0^{\circ}$ mis. $8.7^{\circ}$ moan lemp $13.5^{\circ}$

2b. $\quad 14 x^{\circ} " \quad+16^{\circ} \quad+15^{\circ}$

Steam is blown unt the eave trom the stetm holet

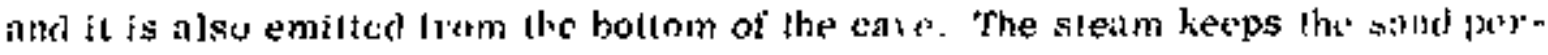

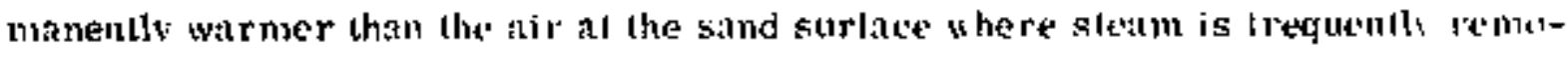
ved by the winds blowing lhrough "ihe Bcll" Conclensiation al watcr is especialth

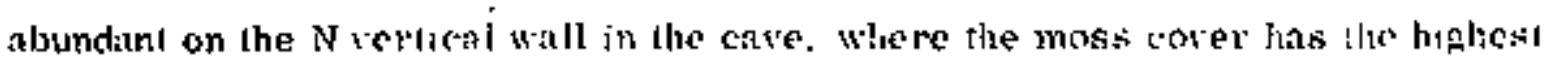

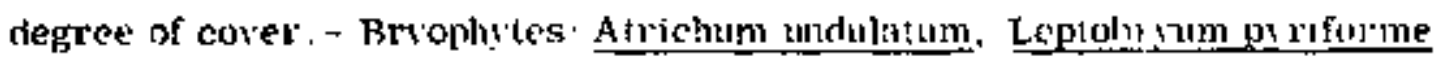


Probes $3 a$ and 4 b (fig, $1: 2)$.

Pusition: Inside "the Bell". (3a ---) at the S wall, 1 m alyove the foultom of the cave. $1 \mathrm{~cm}$ below the surtace in densely packed mosst sand; $(41, \ldots \ldots)$ same locality, sand surface.
$3 a$.
$\max$.
26. $0^{\circ} \min$.
$14.5^{\circ}$
mean temp. $20.9^{\circ}$
Ab.
$22.5^{\circ}$
1
$4.2^{\circ}$
t+
$12.9^{\circ}$

The sand ts kept permanenty warm by the peneirating sterm. Air temperatures are much less, because of the rapid air circulation in the cave.

Probes 5b, 6b and $7 b$ (fig. 1:3).

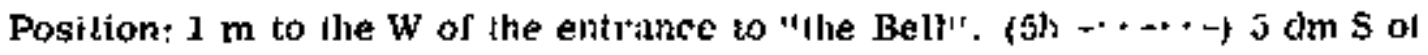
it sleam hole: $(6 \mathrm{~b}, \cdots) 8 \mathrm{dm}$ s of the sleam hole, $(7 \mathrm{~b}, \cdots-) 1 \mathrm{~d}$ din $\mathrm{S}$ of the same steam hole. All the probes at the suxface, hard surface wilh ver! litlle loost windblown sand.

$\begin{array}{lllllll}\text { 5b. } & \max . & 26.2^{\circ} & \text { min. } & 9.4^{\circ} & \text { neant temp. } & 15.5^{\circ} \\ \text { 6b. } & " & 20.4^{\circ} & " & 7.4^{\circ} & 4 & 11.0^{\circ} \\ \text { 7b. } & " & 23.1^{\circ} & " & 8.0^{\circ} & 4 & 11.7^{\circ}\end{array}$

Size of the oval steam hole at the opening, $15-20 \mathrm{~cm}$ in ditumetor. IIm steam is continuously blown out, generally in a soutliward direction down the slope. The steam moves conlinuously over a narrow field from the opening of the hole to 5 $\mathrm{dm}$ to the $\mathrm{S}$ of $\mathrm{il}$. The field between $\mathrm{S}-8 \mathrm{dm}$ is less in conlact with the steam and is wetted by the condensalion of water from the cooled steam. During wind wealher the steam is frequentiv forced down by the wints on to a small area to the s of bl. which explains the higher maximum and mintmum and mean temperatures at probe $7 \mathrm{~b}$ than at fib. There was less wind aster $07.001 .1 / 8$ and the steam could not then reach probe $7 \mathrm{~b}$ so easily. - There is moss cover in a marrow band from $5-8 \mathrm{dm}$ lo the $\mathrm{S}$ of the steam hole. . 
Brvoptivtes: Bryum argenteum, Funaria hygronielrica.

Probes 8a. 9a, 10b and 11b (lig. 1:4).

Position: To the $\mathrm{N}$ of the opening in the roof of the cave. (Sn $\longrightarrow$ ) in densely packed sand $5 \mathrm{~cm}$ below the surface, $2 \mathrm{dm}$ to the $\mathrm{N}$ of the edge of the opening in

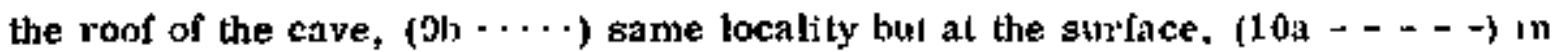
densely packed sand $5 \mathrm{~cm}$ below the surface, $8 \mathrm{dm}$ to the $\mathrm{N}$ of the edge of the opening in the roof of the cave, (11b------) same locality but at the surlace.

$\begin{array}{rcccccc}\text { 8a. } & \text { max. } & 44.6^{\circ} & \text { min. } & 33.4^{\circ} & \text { mean temp. } 39.0^{\circ} \\ \text { 9b. } & " & 27.2^{\circ} & " & 7.8^{\circ} & " & 18.0^{\circ} \\ \text { 10a. } & " & 39.0^{\circ} & " & 30.0^{\circ} & " & 34.3^{\circ} \\ \text { 11b. } & " & 31.2^{\circ} & " & 8.8^{\circ} & " & 17.4^{\circ}\end{array}$

Sleam permanently warms the sand of the root of the cate. The aiv al the surface is, however, cooled down by the permanent turbulence round the cures. Slightly higher maximum and minimum temperatures at 11 b than at 91 might be explnined by random clownward movement of the steam by the winds. Thoue is moss cover between $9 \mathrm{~b}$ and $11 \mathrm{~b}$ where moisture is provided bv the cooled sleam. Bryophvtes: Funaria hygromelrica, Dicranella crispa.

Probes 12a and 13b (ifg. 1:5).

Position: $5 \mathrm{~m}$ SW of "the Bell". botween small stean holes. (12a - ) $\overrightarrow{3} \mathrm{~cm}$ below the surface in densely packed sand; (13b ....) same localıty al the surface.

120. $\max .50 .8^{\circ}$ min. $411^{\circ}$ mean tenup. 4 ti. $1^{n}$

13b. $\quad 28.8^{\circ} \quad " \quad 12.1^{\circ} \quad$ " $\quad 18.2^{\circ}$


These were the highost maximum, minimum and mean temporaturcs recorded with soll thermistors within the area. Turbulence in the air strata close to the ground is most efticient in the localitv, but the high soil temperalures ment tha l 13b recorded the bighest minimum temperalures of the air thermistors in the area - Bryophytes: Bryum argentenm, Pohlia albicans.

Comments: Temperatures in the thermal area in and around "the Bell" are alreadi ins. comparatively high al a deph of $5 \mathrm{~cm}$ in loose sand or tephm Thev arc charecterized by rather small diurnal amplitudes. Low air temperattres at ijight seem to have only a small eflect on the ground temperatures, which are vegulated by the hot steam penetrating from below. The diurnal temperature amplitudes are flus much larger at the soil surtace, as shown espectallv cleatly ly the probes of fig. 1:4. In the temperalure gradienis inducated by Joliancsson (1972, 0. I29 ff.), there is no information about lemperitures between 0-20(30icm depth. His curve of point 11 ("the Bel1"1) inclicales temperatures of ontv $3: 5^{\prime \prime}$ at a depll of $30 \mathrm{~cm}$. which seems to be nuch too low for this area (cf, also Jukobsson 1972. p. 122).

B.

Northern part of "Surtur I" (70-72 $\mathrm{m}$ alove sea level).

Time period: $14 / 814.00-15 / 813.00$ (1972).

Weather: 14/8, 14.00 to $18,00,75-100 \%$ cloud cover, winds $5-10 \mathrm{~m} / \mathrm{sec}$.

15/8, afier 04.00, wnds below $5 \mathrm{~m} / \mathrm{scc}$. and 75-1000 cloud cover.

All measuring points (fig. 2:1-9): Temperalures mensured al intervals of onc hour have been connected in the diagrams. Vatues from 21 prohes will be diseussed below. Probes with numbers followed lar (a) are situated below the soll surface and those by (b) at the surface. 
Probes 1a and $2 \mathrm{~b}$ (ftas. $2: 1\}$.

Position: $2 \mathrm{dm}$ ahove vertical oval opening with sleam emission. Diancier of the hole is 10-15 cm. (1a - $1 \mathrm{~cm}$ below the surface in looscly recunulated mojst sand; $(2 \mathrm{~b} \cdots \cdot)$ same place at the surface.
1a. $\max$
$25.6^{\circ} \mathrm{min}$.
$7.1^{\circ}$
mear. temp. $17.1^{\circ}$
2b.
$24.3^{\circ}$
$9.1^{\circ}$
$"$
$19.9^{\circ}$

Steam emission in the vicintty of the hole dur'sng the molning hours with ralher light wink clearly increases the lemperatures in the air close to the ground surface above the temperntures in the sand. Between 14,00-24 00. lhe winds blow the steam downwards in a SW direclion from the hole (ef, probus 12 a and $]+b$ ).

Probes Ba and 4b (fig. $2: 2$ ).

Position: $3 \mathrm{~m}$ SW of the sime steam hote ns above. (3.1 - ) t d thelm

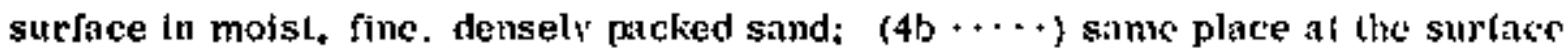
of the sand.
$3 a$.
$\operatorname{mex}$.
$19.2^{\circ} \mathrm{min}$.
$12.2^{\circ}$
meni lemp
$14.5^{\circ}$
to.
$18.7^{\circ}$
$8.9^{\circ}$
$12.4^{\circ}$

The winds ede not conlinuously blow the steam as far as 3 m from the hole Sand lemperalures are thus almost continuonsl" higher than a1r temperatures. Values should be compared with the lower values recorded al 15 and 17 h. at the same distance from the steam hole but in a place with loose sand wherc the percentage content of fine grain malerial is smatl and penetration of stean is applarently ensicr. 
Prcbes 5a and 6b (fig. $2: 3$ ).

Position: $5 \mathrm{~m} \mathrm{E}$ of rim of the craler, on slope facing $\mathrm{E}$. (5a $\longrightarrow 1 \mathrm{~cm}$ below the surface in dry loose sand; $(6 \mathrm{~b} \cdot \ldots)$ same place, at the surface.
5a. max.
17. $9^{\circ} \quad \min$.
8,7
mean
6b.
$18.5^{\circ}$
$7.9^{\circ}$
"
temp. $11.3^{\circ}$

Lowest minimum and maximum ajr temperatures recorded within the area. Comparatively low minlmum temperatures and the lowest maxımum temperalures recorded al a depth of $1 \mathrm{~cm}$ in the area. The lowest mean lemperatures were at these probes.

Probes $7 \mathrm{a}$ and $8 \mathrm{~b}$ (fig. $2: 4$ ).

Position: Rim of crater, $1 \mathrm{~m}$ to the E of steam hole mentoned above and $5 \mathrm{~m}$ W of position of $5 \mathrm{a}$ and fib. (7a -$) 1 \mathrm{~cm}$ below the surface in molst sand; (8b...$)$ ) same place, at the surface.
$7 \mathrm{a}$.
$\max$.
$18.5^{\circ} \mathrm{min}$.
$10,7^{\circ}$
mean temp. $13.0^{\circ}$
bb.
$19.7^{\circ}$
"
$9.6^{\circ}$
11
$13.0^{\circ}$

During morning hours with light winds, onlv slipht influence of slennjprolse 8b, much weaker than at $2 b$. Comparatively low minimum and maximum values at both probes. - Bryophytes: Dicranglla crispa, Leptolsyum pyriforme.

Probes 9a, 10a and 11b (1tg. $2: 5)$.

Position: $3 \mathrm{dm}$ W of sleam hole (same as alxove). (9a - $1 \mathrm{~cm}$ below the surface in moist sand; (10a ----$)$ same place $5 \mathrm{~cm}$ deplh; (11b....) stme place, at the surface. 


\begin{tabular}{|c|c|c|c|c|c|c|}
\hline $9 a$. & $\max$ & $27.2^{\circ}$ & min. & $11.1^{\circ}$ & mean lemp. & $18.9^{\circ}$ \\
\hline Da. & . " & $32.2^{\circ}$ & $"$ & $21.3^{\circ}$ & " & 26.4 \\
\hline & " & $27.6^{\circ}$ & "t & $8.3^{\circ}$ & " & 16.7 \\
\hline
\end{tabular}

There is a steep rise in temperature from the surlace to a depth of $5 \mathrm{~cm}$ in the sand. - Bryophyle: Pohlia nutans. .

Probes 12a, 13a and $14 b$ (fti. $2: 6$ ).

Position: $1 \mathrm{~m} \mathrm{~W}$ of the sleam hole. (12a —) $1 \mathrm{~cm}$ below the surface in moist sand; (13a----) same place, $5 \mathrm{~cm}$ depth; $14 \mathrm{~b} \ldots$. ) same place, at the surface.

12a. $\max .20 .8^{\circ} \min .12 .6^{\circ}$ mean temp. $15.7^{\circ}$

\begin{tabular}{|c|c|c|c|c|c|}
\hline 13a. $\quad " 1$ & $26.7^{\circ}$ & 1 & $18.8^{\circ}$ & $"$ & $21.0^{\circ}$ \\
\hline$d b$. & $24.4^{\circ}$ & " & $9.1^{\circ}$ & " & $15.8^{\circ}$ \\
\hline
\end{tabular}

The three probes measured series of lemperalures of special importance to the unclerstanding of condilions close to steam emission looles. The increase of temperatures with depth of only $5 \mathrm{~cm}$ is verv marked. The air temperatures at the surface are influenced by steam blowing down from the hole in the first hall of the timo pexodidoring the second ta'f the

Tnlluence decreases as the wind decreases. A comparison ol air lemperatures at a distance of $3 \mathrm{dm}$ and $1 \mathrm{~m}$ from the hole stows that the sleam emerges from the hole in a steep upwird direction and then is carried down by winds to the ground further away. These conditions were also observed at probes fib and 7ib outsido "the Bell" (fig, 1:3).

Temperatures very close to a steam hole are evidently subject to larger and more frequent changes (cf. probes $9 \mathrm{a}, 10 \mathrm{a}, 11 \mathrm{~b}$ ) than at a longer distance from it. - Bryophyte: Bryum argenteum. 
Probes 15a, 16a and 17b (fig. 2;7).

Position: $3 \mathrm{~m}$ to the $W$ of the steam hole ( $\mathrm{m} W$ ol $12 \mathrm{a} .13 \mathrm{a}, 14 \mathrm{~b}$ ), (15a - $1 \mathrm{~cm}$ below the surface in moist loose sand deposils: (16a - - - ) same place, at a depth of $5 \mathrm{~cm}$; $(17 \mathrm{~b} \cdot \cdots)$ ) sanie place, at lie surface.

15a, $\max , 24.8^{\circ} \min .16 .9^{\circ}$ mean temp. $19.4^{\circ}$
16a. "
$33.7^{\circ}$
$27.5^{\circ}$
$"$
$30,6^{\circ}$
17b. "
$21.1^{\circ} \quad "$
$9.8^{\circ}$
"
$14.8^{\circ}$

The heat provided from below to the accumulated sand and to the air above in this thermal area also depends on the depth of the deposiled sand layer. There was a much thinner snnd laver above the lava here than al a distance of $3 \mathrm{dm}$ or $1 \mathrm{~m}$ from the steam hole.

Prohes 18a and 19b (fig. $2: 8$ ).

Position: At a distance of $1 \mathrm{~m} W$ of the large sleam holc, $10 \mathrm{~cm}$ from the opening of a small round steam hole with horizontal opening $3 \mathrm{~cm}$ in diameler. $(18 \mathrm{a} \ldots) 1 \mathrm{~cm}$ below the surface in moist joose sand: (19b $\ldots$.... same place, at the surface.
18n. $\max$
80.3 $3^{\circ}$ min.
$25.2^{\circ}$
megut temp, $40.3^{\circ}$
19 क.
$49.4^{\circ}$
$20.1^{\circ}$
$36.2^{n}$

Larrest temperature rangesf recorded within the area both in air and sand. The verv large increase in temperatures behween $03.00-05.00$ can nol be cortelated with similar changes in conditions at the other probes. Temperatures ver: close to sleam holes change rapidly and frequently (ct. 20a, 2lb). 
Prolses 20a and 2lb (fig. 2:9).

Position: At a distance of $1 \mathrm{~m} \mathrm{~W}$ of the big steam hole. $3 \mathrm{~cm}$ from $2 \mathrm{~km} \mathrm{long}$ narrow fissure in the sand. $(20 \mathrm{a} \longrightarrow) 1 \mathrm{~cm}$ below the surface in moist loose sand; $(21 b \cdots+)$ same place, at the suriace.
20a. $\max$.
47. $6^{\circ} \quad$ min.
$39.1^{\circ}$
mean temp. $43.1^{\circ}$
21b.
$55.4^{\circ} \quad$ r
31. $3^{\circ}$
$"$
$46.6^{\circ}$

Highest maximum air temperature recorded. Highest mean lemperatures ball in air and send.

- Bryophyles: Pchlia albicans, Bryum argenteum.

Comments: The series of rccords have shown the same conditions as wilhtn the firsl deseribed area: gencrilly lower lemperatures at the scil surlace lian al a depth of $1 \mathrm{~cm}$ in sand or tephra. The further increalse in lemperatures umlil the depth of' $5 \mathrm{~cm}$ appears to be very steep. Strength and durechom of winds influence air temperatures, in relation to the contribulion of hot steam in localities close to steam enission holes. Depth of accumulaled sand probably has an indluence on amounts of bent pencl rating up to the surface but not on the Irexuency and itme of cliange in temperatures.

Steam from holes and fissures is apparenlly carried by tle wits in a curve from the openting down to areas around, unless the winds are verv week. Anomints of steam emitted depend on the stze of the holes: the direclion of the steam depends on the inclination of the holes and the exposure of the sitution to the wint 


\section{DISCUSSION}

Thermat arens on Surtsoy locally provide suitable conditions for colomaation by mosses. Sttch loenlities are situaled in the vicinity of steam cmission holes and fisstires. In these places there are now colserent moss car'pets w'ilh fairly large degrees of cover. The colonized areas are frequentlv disthetly limiled, with tew specimens growing outside the dense carpets.

The steam provides heal and condensed water to areas close to the cmission holes. It was supposed by Bjarnason \& Fridrihsson (1972, p. 10) that whicr conden sed from the steam is a more probable explatation of the development of brophr te diaspores than the heat. The stabilizing effect of the steitm on the sand was also mentioned. This supposition can be further rcrified.

The large amount of heat with no gleam emission provided to several places in the thermal arca where mosses are absenl supports this idea. There is no incrense in heat towards the onening of big ste:m holes, but oflen a sharp limt of moss cover at some distance from them. However, high lemperatures are foleriled round small emilting holk's. The high lemperatures, often reacling $60^{\circ} \mathrm{C}$, in $\mathrm{rc}$ thus not likely to be able to support or to hinder the moss colonization.

Condensalion of waler lakes place round the stenm holes, up to il certalun dislance not generally reached by the steam. The steam is carried further trom the holes during windy weather. The transport ol steam irom the holes with incluned openings seems to be alwavs in one direction, even if winds are blowing tomards the operning of the hole. For example. this was the case at the laves slum hole at a distance of $1 \mathrm{~m}$ W of "the Bell" on 13/8, when strong Stl winds were blowing. Steum was then first carried from the $\mathbf{S}$-facing opening in a first southwards drec tion. to nearly exactly the far limit of the noss cover situated to the $S$ ot the hole. 
It was then carried by the wind in a curve lowards the $N$. The emission of stean from the holes during very windy conditions takes place in a curved direction in a way probably providing less sten and heat to places very close to the holes and more to a more distant area. These conditions lave been illustrated by the temperature series both from "the Bell" and from "Surtur I".

The correlation between position of moss cover and conitribution of sleam condensation of water - seems to be well-established. Howcver, the reason for the absence of mosses in areas closest to biy steam holes rematins to be discussed. In that connection, the stabilization of sand and finer material by Ule condensed water chould be stressed. In the vicinity of the steim holes, there is oftell a building up of cones of accumulated muterial. The accumulation decteases tway. from the holes and drops rather abrupty to smali amounts at the dar limit of the genera] range of the steam. Just around the holes there is probathly an acctimulation of wind-transported material which is too rapid to allow cliaspores of mosses to develop. Willin the range o[ moss colonization, the water supply is ccrtainly essen'ial but also the stabilization of the substrate, with accumulation nol rapic enough to

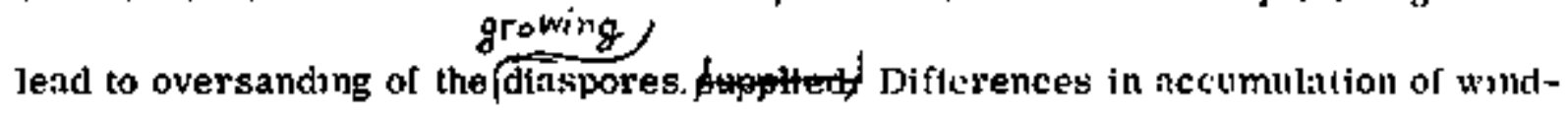
blown matertal might be explained by a more permanent moistomng of the zonc nearest to the holes than in places furither owtiv, in the usual direction or movement of the sterm emitted, whore moss cover is present.

Outside the area reached by the steam, there is a lack of noisture and also frequent change between accumulation and erosion of deposiled material. Sucl heres conditions are unfavourable to the attachment and further development of moss dinspores.

The sizes of the steam emission holes and fissures regulate the amounts of steam provided to the surroundings. The accumulation of wind-blown material 
close to the holes and the building up of cones of ten means that the opemuss are inclined, sttuated on the slopes of the small cones. The rmission of heal and sleam then takes place in onc general direction. The development of a moss corer then depends quantitatively on the amounls of stenm emilted; and its sitution depends on the direction of the steam outflow. A concentric cobereut noss zone round steam holes ts therefore rare. Moss cover is often observed within a marrow segment extending away from the holes.

Temperature records: One of the gencral foatures of lle tompleature sequences within the Iwo measuring arens is the shnrp increase in temperiture from the surface down to a depth of $5 \mathrm{~cm}$. These atre also distinctiv hinher temperatures al $1 \mathrm{em}$ deplh than al the surface. $5 \mathrm{~m}$ sw of "the Bell", the mean tempciature al a depth of $5 \mathrm{~cm}$ in the tephra was within the temperature rande $\left(40-60^{\circ}\right)$, earlier recorded in 1970 at a depth of $20 \mathrm{~cm}$ (ef. Magntisson - Stcinibürusson - Fritlrikssom 1972, p. 83). Temperatures recortod at a depill of $5 \mathrm{~cm}$ in "Surlut I" vere also within the runge of $20-40^{\circ}$, indicated from a slepth of $20 \mathrm{~cm}$ for that area rop.cit.) The further very steap rise in lemperature down to $60 \mathrm{~cm}$ uns recorded by Jakols:son (1972: p. 122). His value's seem to be more probahle than those showing a much less steep gradient, oltained by Joharnesson (1972, p. 137, point 11).

Weakening turbulence may for a short time increase the surtace nir lomperittures close to steam holes above those measurct at a deptl of $1 \mathrm{~cm}$ in the sand, especially if the accumulated sand layer is deep. Diurnal temerature ringes at the surface are larger than within the sand or tephra. The ranges nl 5 cm depth wottd in a larger number of series of records show compacatively very small diurnal ranges with changes not always correlated with day or night. The supply of heal ta the air ncarest the ground close to steam holes is parallel to the supply of stean condensed water. 
To sum up, moss cover on Surtsey is not favoured by he:ll supply. Lncalities are now numerous outside thermal areas. Mosses do not seem to be hindered front colonising habitats where there are continuously high tentjeralures. Lack of water is certafnly limiting factor. Too much supply of water is, however. probutbing also unfavourable, because of the secondary eftect of too rypid an accumulation of windtransported materinl, A moderate water supply is roxuircd, with a tavourable balance between accumulation and wind-erosion of supplied sand of liner material.

\section{ACKNOWLEDGMENTS}

The work on which this paper is based was sponsored by the Surlsev Research Society with a grant from the $v_{+}$. Alomic Energy Commision, Division of Piolonv. and Medicine. 

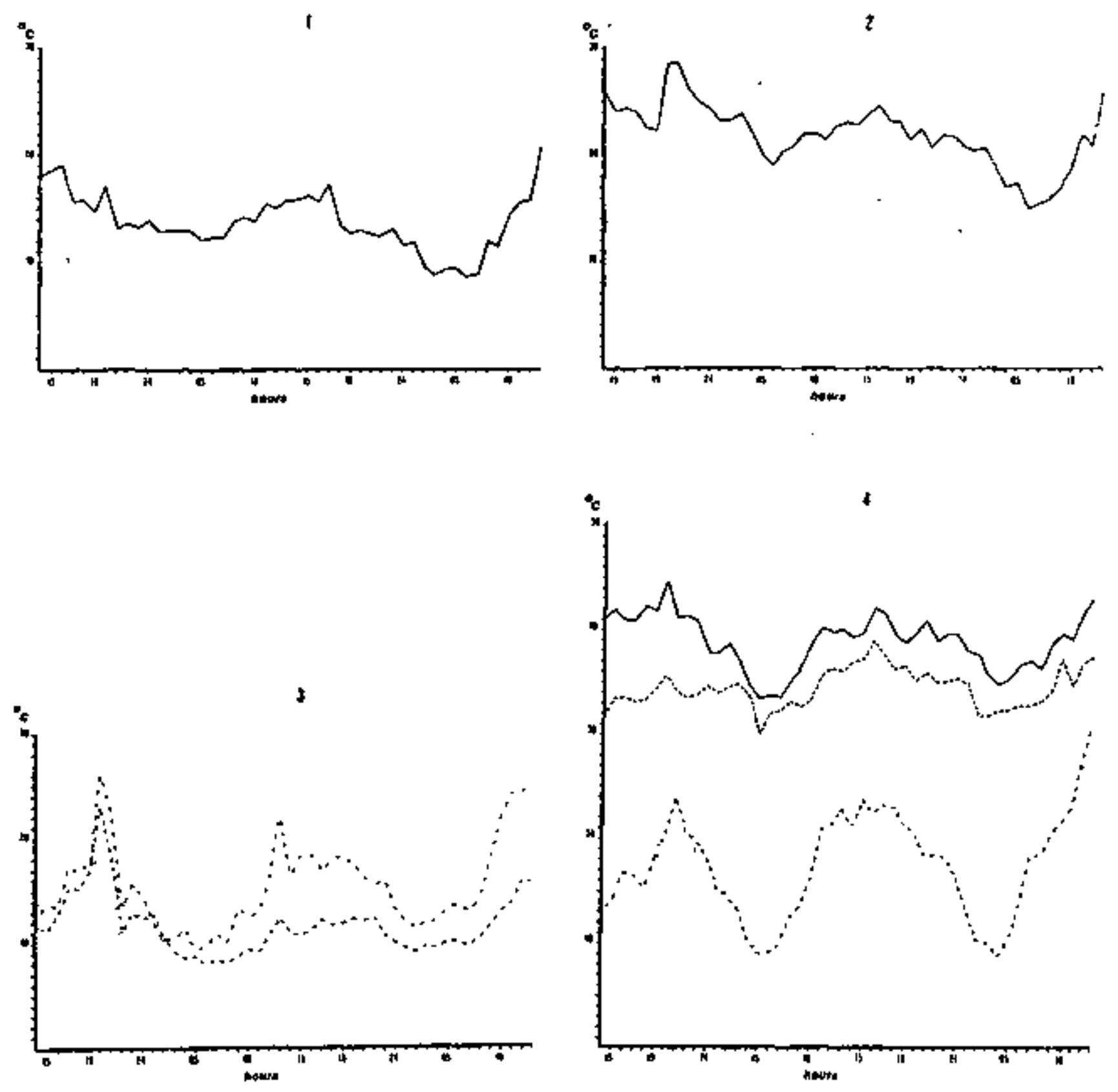

$7 g .1: 1-4$ 


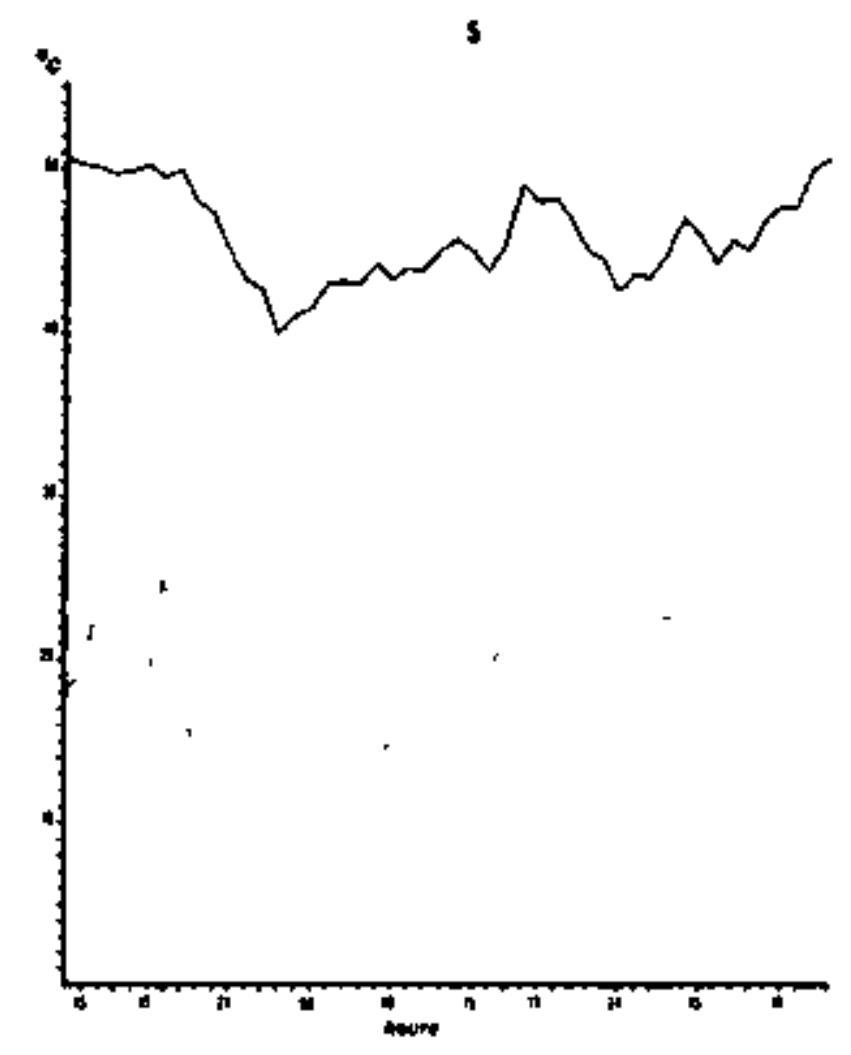

Fig. $1: 5$. 

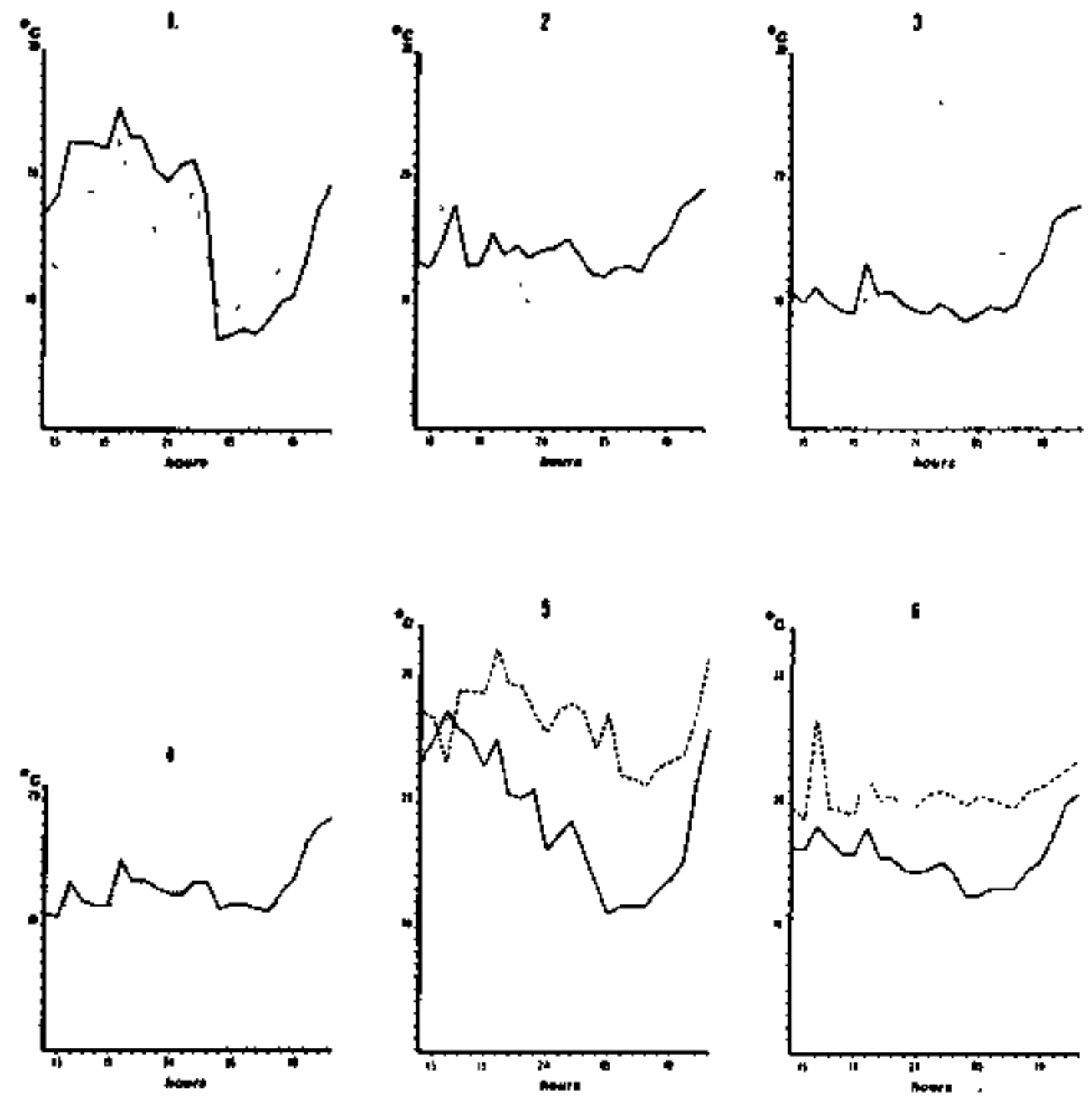

Tig. $2: 1-6$

Surtisey 

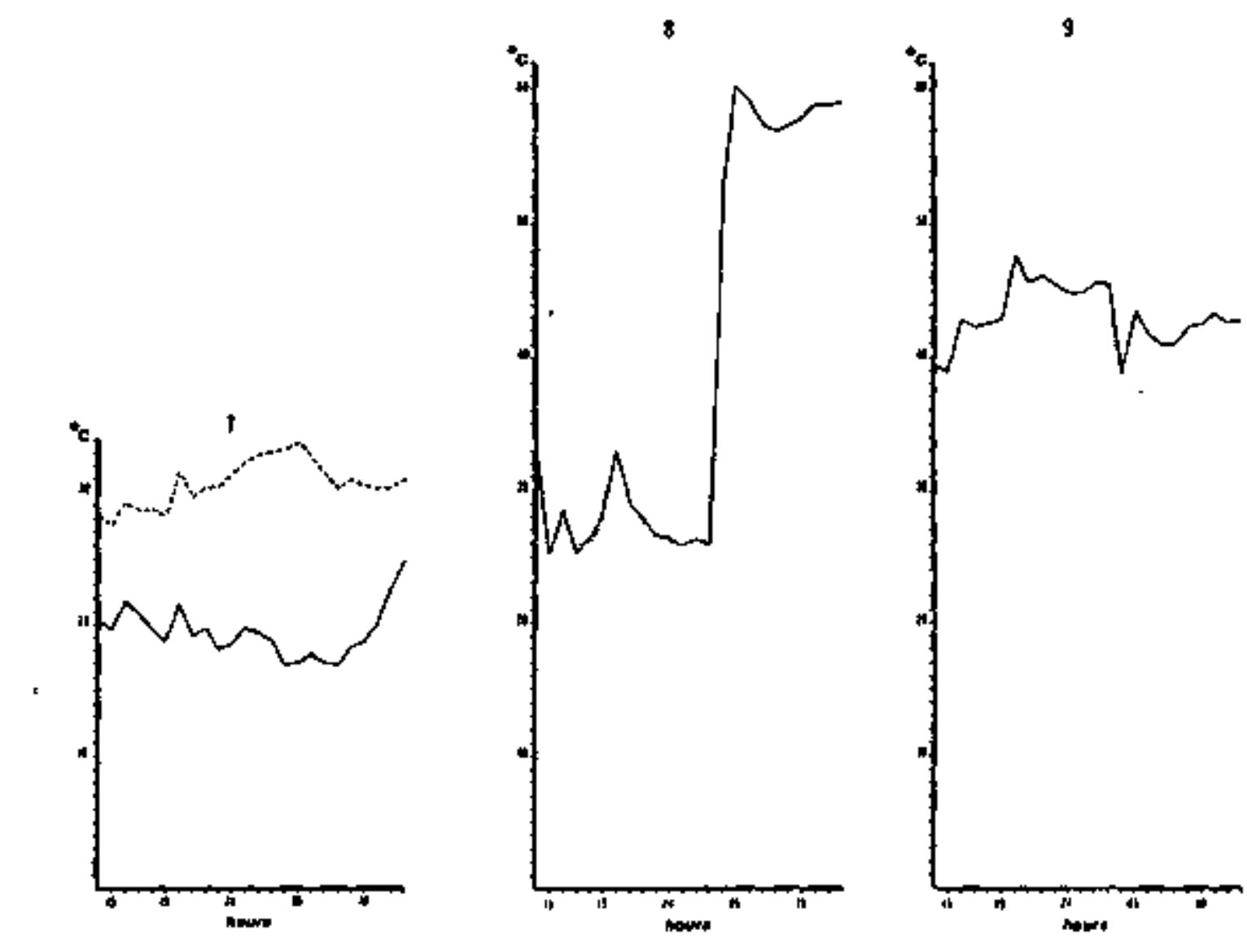

Fg. $2: 7-\%$ 
(fig. texts)

Fig. 1:1-5. Temperatures recorded with 13 thermistor probes at intervals of 1 hour, inside and close to "the Bell", section $\mathrm{J} 13$ in the thermal area. (The position of the probes is described in the text.)

Fig. 2:1-9. Temperatures recorded with 19 thermistor probes in the $\mathrm{N}$ part of "Surtur I" and with 2 probes outside the craler, section $L 12$ in the thermal area. (The position of the probes is described in the text.)

Fit. 3. "The Bell", situaled on the $\mathrm{S}$ facing slope to the $\mathrm{N}$ of the criler "Surtur I". Sleam emission from several places in the aten. - 14.8.1972. F. Sjn.

Fig. 4. "The Bell" seen from $\mathrm{S}$ (cf. temperature diagrams fig. 1: 1-5). In the foreground, probes $12 \mathrm{a}$ and $13 \mathrm{~b}$ (fig. $1: 5$ ). To the left, prohes $5 \mathrm{~b}$, fib and $7 \mathrm{~b}$ (fig. $1: 3$ ), located $1 \mathrm{~m} W$ of the entrance to the cave and to the $S$ of the sleam hcle. 14.8.1972. E. Sjn.

Fig. 5. Northernmost part or "Surtur "t" with temperature recording ins/rument (cf. fig. 2:1-9). To the left, prohes 18a, 19b, 20a and $21 \mathrm{~b}$ (fig. $2: 8,9$. To the right, rim of erater, postion of probes 7 a and 8 b (fig. 2 ;4). Behind the instrumenl, which was protected by a plastic envelope, are prolues 1a. 2b, 9n, 10 a and $11 \mathrm{~b}$ (Cig, $2: 1,5) .=15.8 .1972$, E. Sjn.

Fig. 6. "Surtur I" seen from the N from the slope just below "the Bell". The location of the temperature recording insirument is visilyie. Steam emission from the area is strong. - 15.8.1972. E. \$jn. 
R E F E R E N C E S

Bjarnason, A. H. and Fridriksson S. (1972): Moss on Surtsey, Summer 1969. Surtsey Research Progress Report VI, 9-10.

Frldriksson S+, Bjarnason A. H. and Sveinbjornsson, B. (1972): Vascular Plants in Surtsey 1969. Ibid. VI, 30-39.

Fridriksson S., Magnússon S. and Sveinbjörnsson B. (1972): Vegetation ori Surtsey - Summer 1970. Ibld.VI, \$4.59.

Fridriksson S., Magnisson S. and Sveinbjorasson B. (1972) : Substrate Map of Surtsey 1970. Ibid, VI, 60-63.

Jakobsson S. P. (1972): On the Consolidation and Palagonitization of the Tephra of the Surtsey Volcanic Island, Iceland. Ibid. VI, 121-128.

Jöbannesson A. (1972): Report on Geothermal Observations on the Island of Surtsey. Ibid. VI, 129-136.

Magtứsson S., Sveinbjörnsson B. and Fridriksson S. (1972): Substrate Temperature Measurements and Location of Thermal Areas on Surtsey, Summer 1970. Ibid. VI, 82-84.

Sigtryggsson H. (1970): Pretiminary Report on the Results of Meteotological Observations on Surtsey 1\%68. Surtsey Research Progress Report V, 119-120.

Thorarinsson S. (1968): The Surtsey Eruption. Course of events during the year 1967. Surtsey Research Progress Report IV, 143-148. 